\title{
Parametric multi-objective energy and cost analysis in the life cycle of nearly zero energy buildings - an exhaustive search approach
}

\author{
Tobias Weiss ${ }^{1,}$, Christoph Moser $^{1}$, David Venus $^{1}$, Björn Berggren $^{2}$, and Ase Togerro ${ }^{2}$ \\ ${ }^{1}$ AEE - Institute for Sustainable Technologies, Gleisdorf, Austria \\ ${ }^{2}$ Skanska Sverige AB, Stockholm, Sweden
}

Received: 22 May 2019 / Accepted: 19 September 2019

\begin{abstract}
Possible cost saving potentials in planning and construction of high performing nearly zero energy buildings (nZEBs) with advanced energy standards are often not sufficiently assessed, as only a few, out of numerous possible variants of technology sets are considered in the traditional planning process. Often planning and analysis are not carried out in parallel, and the alternative technical options are discarded at an early stage. If, on the other hand, possible variants are realistically compared in the planning phase, a profound decision can be made. nZEB-design is also a multi-objective optimization problem where stakeholder interests' conflict with each other. This research addresses a methodological approach to better understand the effects that technical variables have on energy, environmental and economic performance over the whole life cycle of a multi-family residential building in Sweden. The research goal is to identify the most significant technical nZEB design variables organized into a consistent framework. In this paper, in a first step an exhaustive search method is assessed for a multi-family residential building in Sweden that systematically investigates all possible variant combinations. In a second step the derived results are applied to multiple objectives and optimisation goals for a multi-target decision-making framework so that different actors can decide between optimal solutions for different objectives. This approach seeks to explore a set of optimal solutions rather than to find a single optimal solution. On the one hand, a variety of technologies, such as insulation of the building envelope, ventilation or electricity and heat supply, and on the other hand a variation of the boundary conditions (such as observation period, user behaviour, energy price increases or $\mathrm{CO}_{2}$ costs) was investigated. The results were analysed energetically and economically over the life cycle of the building with the objectives of identifying coherences, deriving trends and optimizations over a time span of 40 years. The results show that the variance in the financing costs $(20 \%)$ and the net present value $(15 \%)$ is relatively low, whereas the primary energy demand $(66 \%)$ and the $\mathrm{CO}_{2}(73 \%)$ emission vary in a broader range. The optimum cost curve in relation to $\mathrm{CO}_{2}$ emissions is very flat. Low emissions and energy requirements can, therefore, be achieved with different energy concepts as long as the envelope is very efficient. Due to the nature of an exhaustive search approach, it is also possible to find technical solution sets and design strategies with nearly equal financing cost and/or net present values, but with less primary energy consumption and/or $\mathrm{CO}_{2}$ emissions.
\end{abstract}

Keywords: Life cycle costs / nearly zero ernergy buildings / multi-objective energy and cost analysis

\section{Introduction}

Cost optimal and nearly zero-energy performance levels are principles initiated by the European Union's Energy Performance of Buildings Directive, which was recast in 2010 [1]. Since its introduction as part of the EPBD recast, a vast number of studies of the defined cost-optimal analysis have been carried out.

\footnotetext{
* e-mail: t.weiss@aee.at
}

The implementation of the cost-optimal approach has led to a strong scientific interest in this field, by research institutions and by the EU member states [2-7]. In addition to regulative requirements, the term "cost-optimal level" refers to "the energy performance level leading to the lowest total cost over the estimated economic life cycle" [1]. While nZEBs realised so far have clearly shown that the nearly zero-energy target can be achieved using existing technologies and practices, most experts agree that a broad-scale shift towards nearly zero-energy buildings requires significant adjustments to current building market structures [8]. Cost-effective integration of efficient solution sets and 
renewable energy systems are the major challenges [9]. It has to be noted that the total costs, as intended for costoptimal calculations, only take into account energy-related costs. Therefore, the concept of total costs as foreseen in the revised EBPD is not in line with a full life cycle assessment according to ISO 15686 [10]. Furthermore, in recent years simulation-based optimization methods for detailed building energy performance and cost assessment have evolved, leading to new research on the cost-optimal design of new buildings from a multiple-objective perspective [11]. Still there is an ongoing discussion on the ideal technical design solutions that offer optimal energy, environmental and economic performance.

For that reason, multi-objective optimization analysis has become popular in recent years. In comprehensive review studies, various multi-objective approaches for building energy design were proposed, as summarized by [12-16]. The multi-objective approach used in these studies is usually based on the concept of Pareto frontier and genetic algorithms: The basic concept of Genetic Algorithms is designed to simulate processes in the natural system necessary for evolution [17]. A solution is optimal when no other feasible solution improves one of the objectives without affecting at least one of the other. In that case, the multi-objective algorithms generate a set of solutions, known as the Pareto front. If the problem includes only two objectives, the Pareto front is a twodimensional curve [11].

Genetic algorithms were applied and further optimized within extensive frameworks for cost-optimal and nearly zero-energy building solutions by considering the minimization of energy demand $/ \mathrm{CO}_{2}$ emissions and investment or lifecycle costs as objectives [16-18]. The optimisation of energy and life cycle cost parameters has especially been tackled by Tuhus-Dubrow [19] who optimised several parameters of building shape and envelope features of a residential building to minimise life- cycle cost. In the same way, Wang et al. combined life-cycle cost and lifeenvironmental impact, identifying a number of Pareto optimal solutions for green building design in the early design phase. Furthermore Wright et al. [20] presented a multi-objective optimisation of HVAC system using a Genetic Algorithm based on energy cost and thermal comfort.

Authors of recent publications have also implemented sophisticated sensitivity analysis techniques for nZEB design [21-23]. Some techniques only interfere with one parameter at a time by keeping the other inputs fixed or by using sampling procedures [24], such as Monte Carlo methods [25], to interfere with multi-parameter inputs while simulating only some of the total design combinations that may exist. These methods are especially helpful when computing power is limited.

Optimisation using a "parametric optimiser" offers the advantage that the variants are optimised for a specific goal or cost function and can be found depending on the optimisation objective. Results, therefore, are usually based on two optimisation objectives like for example cost and energy demand. If this concept is also be applied to three or more optimisation goals, the results are more challenging to analyse. Also, most studies based genetic algorithms do not allow any statement on maxima, minima or statistical distributions of the resulting variants.

\section{Methods}

\subsection{Exhaustive search method}

The term "parametric analysis" in this paper is defined by a brute-force algorithm in which a series of calculations are run by a computer program, systematically changing the value of parameters associated with one or more design variables. Brute-force is an exhaustive search method that systematically takes into account all possible variants for a given solution and checking whether each variant satisfies the problem statement [26]. It is based on trial and error where the computer's fast processing power is used to solve a problem, rather than to apply advanced genetic algorithms. Therefore, with the brute-force method the investigation of all possible variant combinations, all solutions are considered. It offers the advantage that statistical evaluations can be made and distributions can be derived. The most significant benefit is, that this concept can also be applied to more than two objectives or optimisation goals. It therefore, provides a sound basis for a multi-target decision-making framework, so that different actors can decide between optimal solutions for different objectives. This approach seeks to explore a set of optimal solutions rather than to find a single optimal solution [27].

A big disadvantage is the vast number of variants, by solving the problem by checking all the possible cases which are slow. Tue to its time complexity based on the limited computational power of calculation the possibility of several thousand variants it also restricts the calculation methods. If, for example, dynamic building simulations are used to analyse a building, where each simulation takes several hours, it is hardly possible to calculate thousands of variants with a manageable amount of computing time.

The difference between a conventional design method and the parametric optimization with an exhaustive search method is shown in Figure 1.

The advantage of the conventional search of the optima usually lies in the manageable number of variants and thus the reasonable effort. The disadvantage, as shown in Figure 1 is that only a local optimum can be found and not the best global solution or efficient neighbours. For example, it allows finding near-optimal design alternatives, not merely the optimum.

The method of energy-economic analysis is shown in Figure 2.

This method is based on the ISO 15686-5 [10] for life-cycle cost calculation and the PHPP software [29] automated by a VBA macro that has been developed by the authors. With this method, more than 30,000 different variants per case could be calculated in a manageable amount of time.

The ISO $15686-5$ provides the main principles and features of an LCC calculation, while the European Code of Measurement describes an EU-harmonised structure for the breakdown of the building elements, services, and processes, in order to enable a comprehensive evaluation of the building life costs in this study. 


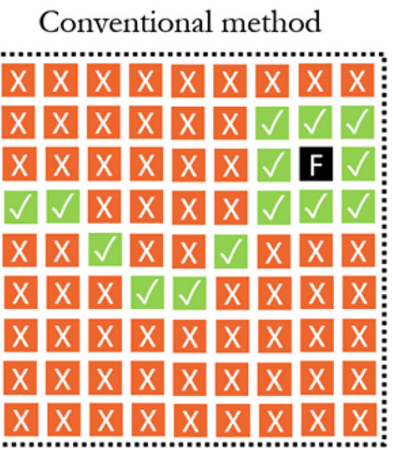

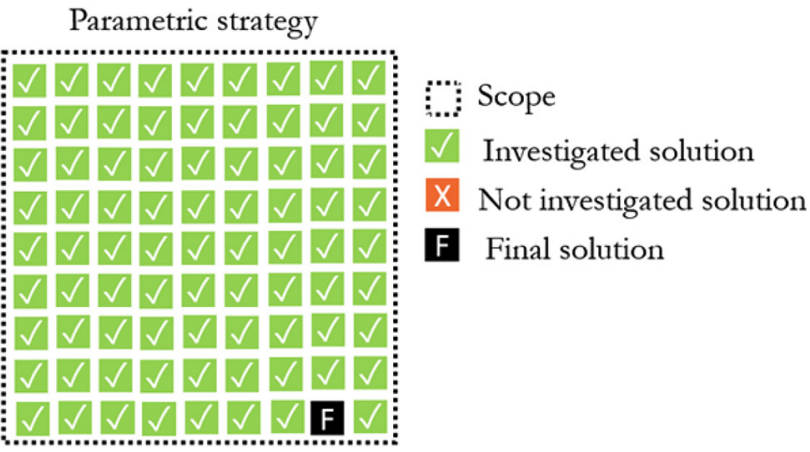

Fig. 1. Comparison of conventional optimisation method vs. parametric analysis [28].

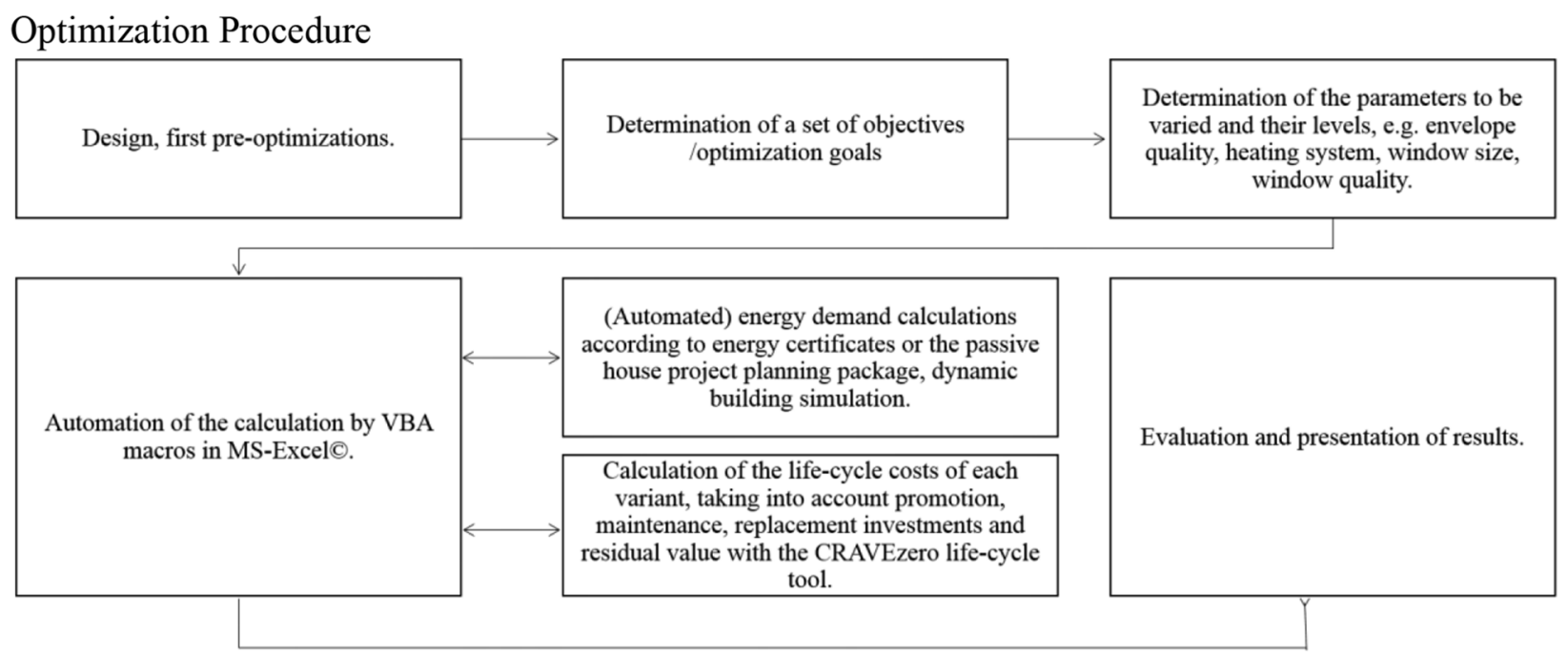

Fig. 2. Method of energy-economic analysis - coupling between PHPP and CRAVEzero LCC tool.

The software PHPP 9 has been used for energy performance analysis. This tool summarises all the information dealing with the energy-related features of the building components and services and provides a comprehensive overview of the technologies installed.

\subsection{Life cycle cost calculation}

According to the ISO 15686-5:2008, the LCC of a building is the Net Present Value (NPV), that is the sum of the discounted costs, revenue streams, and value during the phases of the selected period of the life cycle according to Table 1.

Accordingly, the NPV is calculated as follows:

$$
X_{N P V}=\sum_{n=1}^{p} \frac{C_{n}}{(1+d)^{n}}
$$

$C$ : cost occurred in year $n$; $d$ : expected real discount rate per annum (assumed as 1.51\%); $n$ : number of years between the base date and the occurrence of the cost; $p$ : period of analysis (40 years).
The analysis is based on standard values from EN 15459:2018 that provides yearly maintenance costs for each element, including operation, repair, and service, as a percentage of the initial construction cost. A detailed overview of the input parameters and boundary conditions can be found in the appendix.

In order to provide a homogeneous and comparable estimation of the energy costs, the evaluation is based on the calculated energy demand by using the PHPP evaluation tool [29].

In particular, for estimating both the costs and the revenues (due to the renewables installed). The energy produced from renewables is considered in the energy balance as a positive contribution to the energy consumption, and the revenues from the renewable have been discounted from the energy costs.

\subsection{Boundary conditions}

The construction costs, were provided by Skanska Sweden and are based on current market prices in Sweden for the year 2018. Details can be found in Table A5 in the 
Table 1. Overview of the included costs of the life cycle cost calculation.

\begin{tabular}{|c|c|c|c|c|}
\hline & & & Life cycle phases & Included costs \\
\hline \multirow{6}{*}{$\begin{array}{l}\text { Whole-life } \\
\text { cycle costs }\end{array}$} & & & $\begin{array}{l}\text { 1. Political decision and } \\
\text { urban design phase }\end{array}$ & $\begin{array}{l}\text { Non-construction cost } \\
\text { (cost of land, fees and } \\
\text { enabling costs, externalities) }\end{array}$ \\
\hline & \multirow{5}{*}{ Life-cycle cost } & \multirow[t]{2}{*}{$\begin{array}{l}\text { Initial } \\
\text { investment }\end{array}$} & 2. Building design phase & Building design costs \\
\hline & & & 3. Construction phase & $\begin{array}{l}\text { Construction and building } \\
\text { site management costs }\end{array}$ \\
\hline & & \multirow[t]{3}{*}{-} & 4. Operation phase & Energy and ordinary maintenance costs \\
\hline & & & 5. Renovation phase & Repair and renovation costs \\
\hline & & & $\begin{array}{l}\text { 6. Recycling, dismantling and } \\
\text { reuse phase }\end{array}$ & Residual value of the elements \\
\hline
\end{tabular}

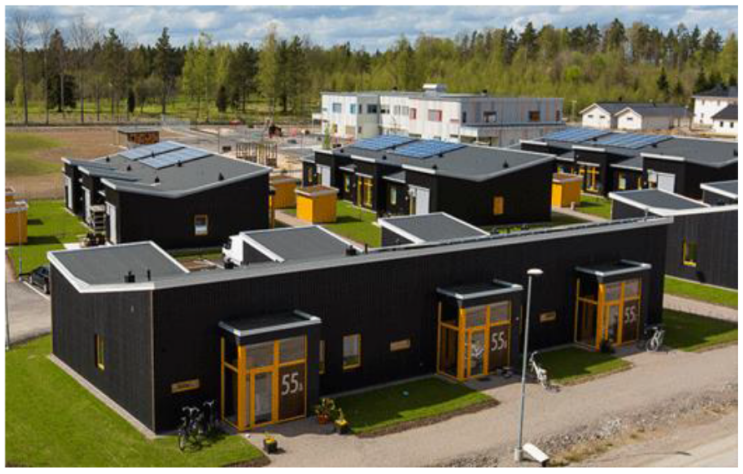

General information

Fig. 3. Case study Solallén.

appendix. The building has already been constructed, and real cost data is available. The costs for the varied technologies and building elements were also directly provided by Skanska. All costs are reported as "net costs" (excluding VAT). Land costs and excavation costs were taken into account. The real cost data was provided $\mathrm{b}$ on the basis of the year 2015. The economic evaluation of the variants is based on an observation period of 40 years. As a financing scheme, a bank loan was chosen with a credit period time of 25 years and an interest rate of $3 \%$. The equity interest rate for the equity investment was set to $1.51 \%$, the inflation rate to $2 \%$ and the discount rate of the used capital investment was 3\%. Further information about different technical maintenance costs and lifespans of the different components, energy price increase taken into account can be seen in the appendix.

\section{Description of the case study}

The methodology was prototypically implemented in the case study Solallén. The seven, freestanding buildings (Fig. 3) are well insulated and using 50\% less energy according to the national Swedish building code requirement. Each building has an annual energy demand of $30 \mathrm{kWh} / \mathrm{m}^{2}$, a photovoltaic system on the roof and a geothermal heating and cooling system, which led to a net zero primary energy balance. During the construction phase, a reduction of $37 \%$ of embodied carbon saving was achieved by using foundation materials efficiently and minimising construction equipment. Figure 4 shows the breakdown of the predicted life cycle costs of the building according to ISO 15686-5 over a time period of 40 years.

\subsection{Variants and sensitivity analysis}

Table 2 shows an overview of the investigated technologies. For each technology, different parameters were varied, which can be classified into a maximum of three levels.

Multiple decision variables were considered for the building envelope, the heating system, the ventilation and air conditioning (HVAC) systems, on-site energy generation systems or energy tariffs. Examples of the objectives are minimisation of environmental impacts (energy consumption, carbon emissions etc.), costs (investment costs, operating costs, life-cycle costs), equipment size (energy generation units, HVAC system etc.), and/or maximisation of indoor air quality, energy efficiency, etc. These objectives were automatically calculated simultaneously, with multiple-objectives. 


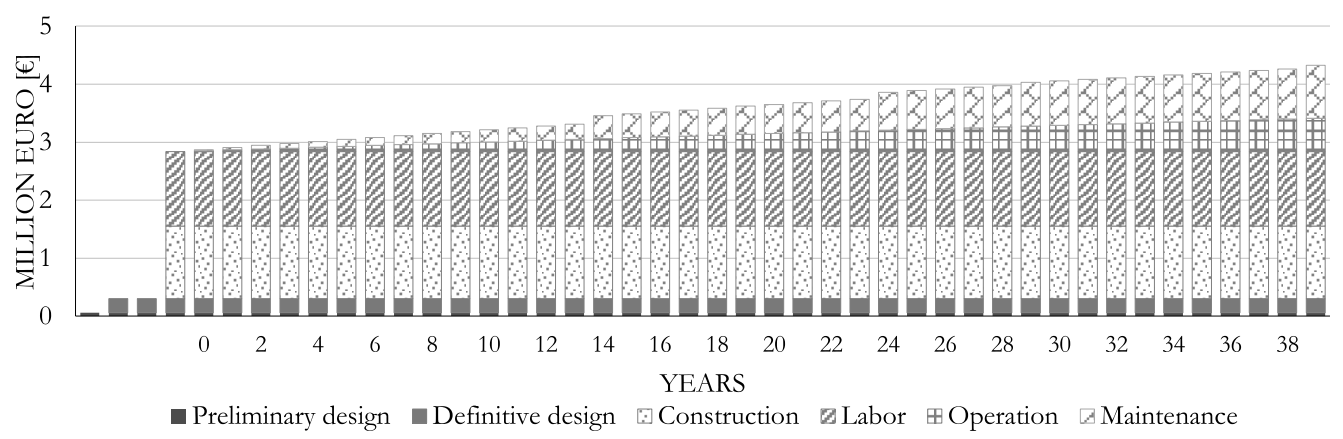

Cost Distribution

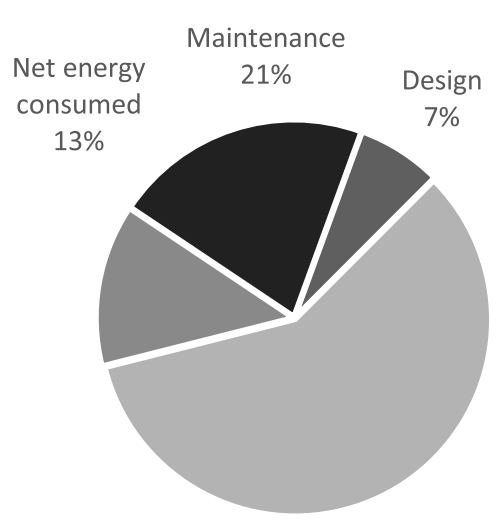

Costruction

\section{Breakdown of the Life Cycle Cost}

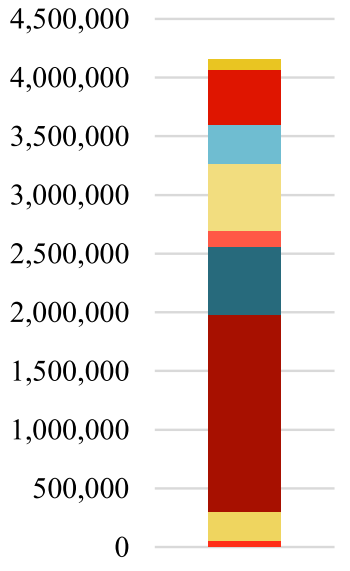

Fig. 4. Life Cycle Costs of case study Sollalen according to ISO 15686-5-"as-built scenario".

Table 2. Overview of the investigated technologies and parameters.

\begin{tabular}{|c|c|c|c|}
\hline Parameter & Level 1 & Level 2 & Level 3 \\
\hline \multirow{3}{*}{ Parameter 1: Insulation } & Floor-slab: $200 \mathrm{~mm}$ insulation & \multicolumn{2}{|c|}{ Floor-slab: $300 \mathrm{~mm}$ insulation Floor-slab: $400 \mathrm{~mm}$ insulation } \\
\hline & Exterior walls: $250 \mathrm{~mm}$ ins. & Exterior walls: $455 \mathrm{~mm}$ & Exterior walls: $600 \mathrm{~mm}$ ins. \\
\hline & & Roof: $600 \mathrm{~mm}$ insulation & \\
\hline $\begin{array}{l}\text { Parameter 2: Air } \\
\text { tightness }\end{array}$ & $\mathrm{n} 50: 1.51 / \mathrm{h}$ & n50: $0.841 / \mathrm{h}$ & n50: $0.41 / \mathrm{h}$ \\
\hline Parameter 3: Windows & $1.10 \mathrm{~W} /\left(\mathrm{m}^{2} \mathrm{~K}\right)$ & $0.90 \mathrm{~W} /\left(\mathrm{m}^{2} \mathrm{~K}\right)$ & $0.70 \mathrm{~W} /\left(\mathrm{m}^{2} \mathrm{~K}\right)$ \\
\hline $\begin{array}{l}\text { Parameter 4: } \\
\text { Ventilation }\end{array}$ & SFP: $1.75 / \eta: 80 \%$ & SFP: $1.5 / \eta: 85 \%$ & SFP: $1.25 / \eta: 90 \%$ \\
\hline Parameter 5: Heating & $\begin{array}{l}\text { District heating } / \infty \mathrm{kW}_{\text {th }} \\
\text { SCOP: } 1.0\end{array}$ & $\begin{array}{l}\text { Ground source heat pump: } \\
4 \mathrm{~kW}_{\text {th }} \text { SCOP: } 3.5\end{array}$ & $\begin{array}{l}\text { Ground source heat pump: } \\
5 \mathrm{~kW}_{\text {th }} / \text { SCOP: } 5.0\end{array}$ \\
\hline Parameter 6: PVs & No PV & $0.0347 \mathrm{~kW}_{\mathrm{p}} / \mathrm{m}_{\mathrm{GFA}}^{2}$ & $0.0624 \mathrm{~kW}_{\mathrm{p}} / \mathrm{m}_{\mathrm{GFA}}^{2}$ \\
\hline $\begin{array}{l}\text { Parameter } 7 \text { : Solar } \\
\text { Thermal }\end{array}$ & No solar thermal & $\begin{array}{l}0.0334 \mathrm{~m}^{2} \mathrm{col} / \mathrm{m}_{\mathrm{GFA}}^{2} \\
\text { standard flat plate collector/ } \\
\text { used for DHW }\end{array}$ & $\begin{array}{l}0.067 \mathrm{~m}^{2} \text { col } / \mathrm{m}^{2} \mathrm{GFA}, \text { vacuum } \\
\text { tubes/used for DHW \& } \\
\text { heating }\end{array}$ \\
\hline Parameter 8: Cooling & $\begin{array}{l}\text { Compressor cooling: } 3 \mathrm{~kW}_{\text {th }} \\
\text { SCOP: } 3\end{array}$ & $\begin{array}{l}\text { Free cooling/boreholes: } \\
1 \mathrm{~kW}_{\text {th }} \\
\text { SCOP: } 20\end{array}$ & $\begin{array}{l}\text { Free cooling/boreholes: } \\
2 \mathrm{~kW}_{\text {th }} \\
\text { SCOP: } 20\end{array}$ \\
\hline \multirow{3}{*}{$\begin{array}{l}\text { Parameter 9: } \\
\text { User behavior }\end{array}$} & Plug loads and lighting: & Plug loads and lighting: & Plug loads and lighting: \\
\hline & $20 \mathrm{kWh} /\left(\mathrm{m}^{2} \mathrm{a}\right)$ & $26.6 \mathrm{kWh} /\left(\mathrm{m}^{2} \mathrm{a}\right)$ & $35 \mathrm{kWh} /\left(\mathrm{m}^{2} \mathrm{a}\right)$ \\
\hline & DHW: $15 \mathrm{kWh} /\left(\mathrm{m}^{2} \mathrm{a}\right)$ & DHW: $17.2 \mathrm{kWh} /\left(\mathrm{m}^{2} \mathrm{a}\right)$ & DHW: $25 \mathrm{kWh} /\left(\mathrm{m}^{2} \mathrm{a}\right)$ \\
\hline Parameter 10: & Electricity: $0.06 € / \mathrm{kWh}$ & Electricity: $0.08 € / \mathrm{kWh}$ & Electricity: $0.1 € / \mathrm{kWh}$ \\
\hline Energy tariffs & District heating: $0.035 € / \mathrm{kWh}$ & District heating: $0.05 € / \mathrm{kWh}$ & District heating: $0.065 € / \mathrm{kWh}$ \\
\hline
\end{tabular}




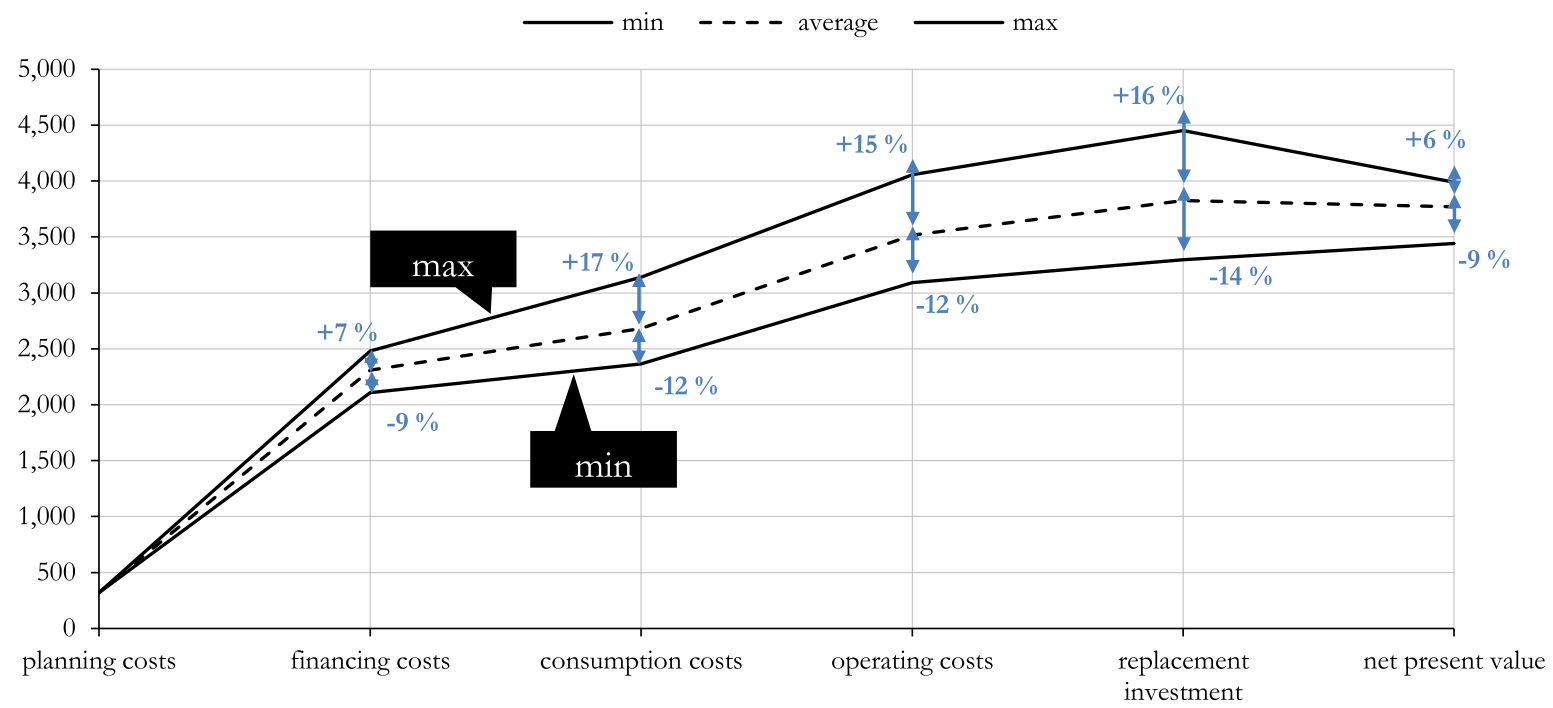

Fig. 5. Specific costs $\left(€ / \mathrm{m}^{2}\right)$ in the different phases of the case study Solallén over the 40 year life-cycle of the building; range between the different parameters indicated as minimum ( $\min )$, average and maximum ( $\max$ ) values; percentages represent the deviation from the average (energy tariff standard/user behaviour standard/without consideration of subsidies).

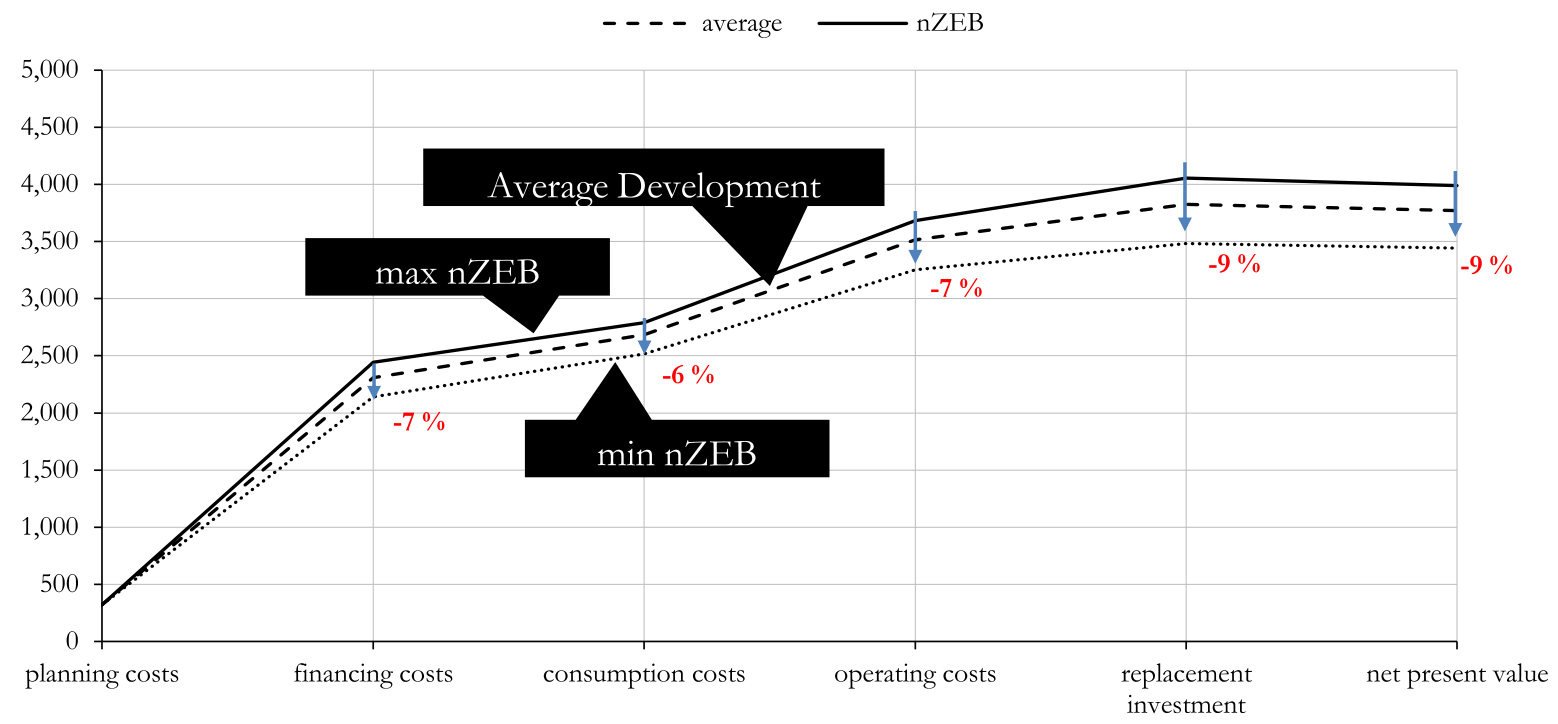

Fig. 6. Cost performance $\left.\left(€ / \mathrm{m}^{2}\right)\right)$ of the case study Solallén over the whole life-cycle of the building; comparison of nZEB variant and the average value deveolpment (energy tariff standard/user behaviour standard/without consideration of subsidies).

\section{Results}

In total, more than 30,000 different variants were calculated. For the results in Figure 5 the minimum, average and maximum values of all those variants were plotted below, indicating the range of the costs in each phase of the building life-cycle. The decline of the net present value is caused by the residual value of the building components, which did not reach the end of their lifespan after the reinvestment. Their residual values are deducted at the end of the observation period.

Figure 6 shows the cost curve for two different variants of the parametric calculations. For the nearly zero-energy building (nZEB) the variant with the highest net present value was plotted. In comparison to that, the variant with the lowest net present value was selected and illustrated. This variant is called "min nZEB". The percentages in Figure 6 represent the possible cost reductions of the "min nZEB" in comparison to the "max nZEB" variant. In this case, $6-9 \%$ reductions in each phase is possible.

Furthermore, if only the financing costs of all variants are plotted in a scatter plot against the calculated $\mathrm{CO}_{2}$ related annual emissions caused by building operation (Fig. 7) the analysis shows that similar financing costs can be achieved by the variants leftmost in the diagram and the variants rightmost. With these similar financing costs, the balanced $\mathrm{CO}_{2}$ emission can be reduced by nearly $70 \%$.

Looking at the net present value of all calculated parameters in relation to the balanced $\mathrm{CO}_{2}$ emission in 


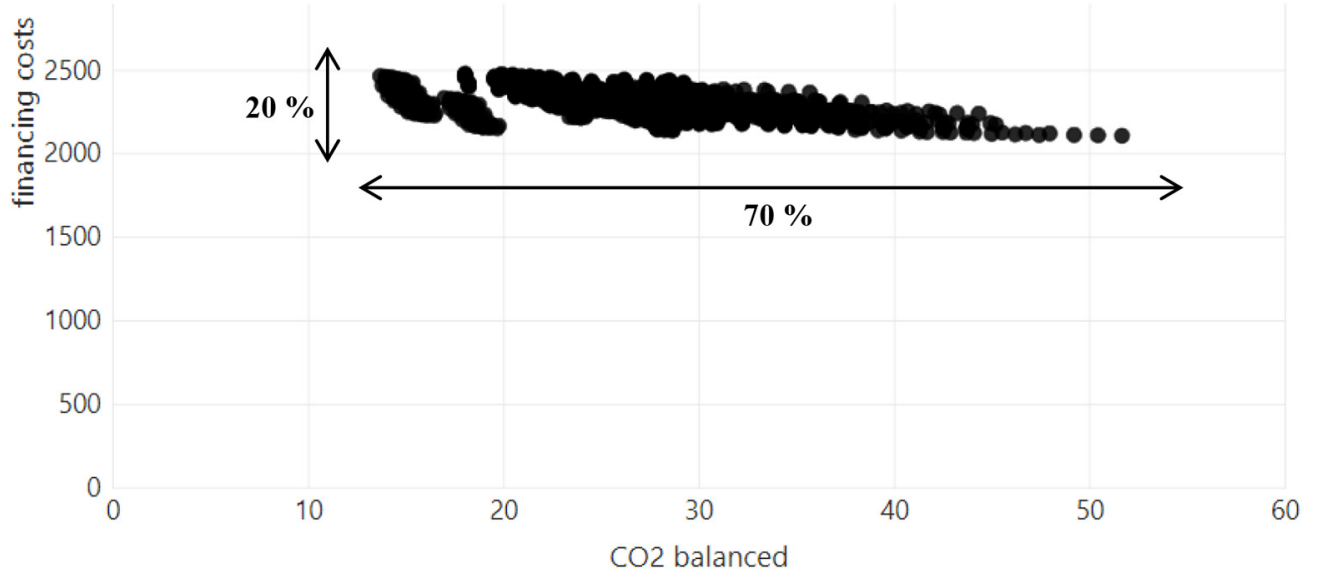

Fig. 7. Financing costs $\left(€ /\left(\mathrm{m}^{2}\right)\right)$ in relation to the balanced $\mathrm{CO}_{2}$ emissions $\left(\mathrm{kg}_{\mathrm{CO} 2} /\left(\mathrm{m}^{2} \mathrm{a}\right)\right)$ of all variants of the case study Solallén (related to the treated floor area of the $\mathrm{PHPP} / \mathrm{CO}_{2}$ factors $\mathrm{PHI} /$ without consideration of subsidies).

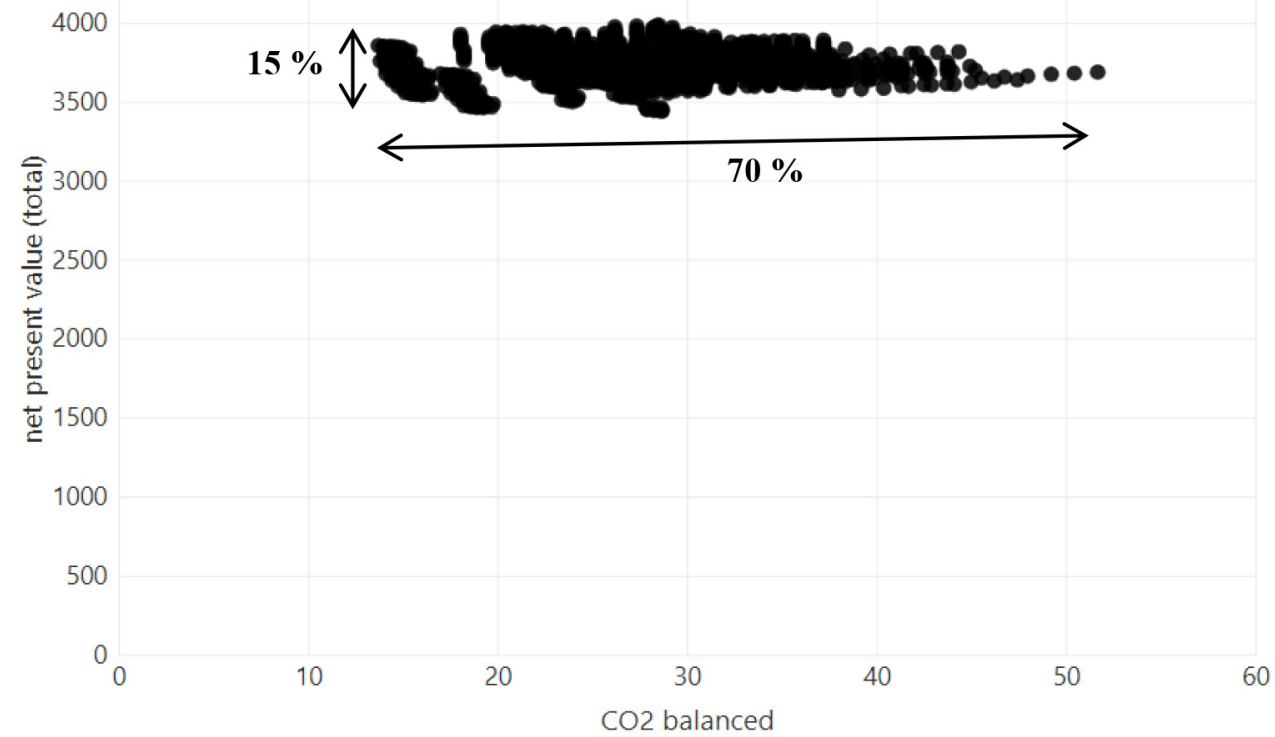

Fig. 8. Net present value $\left(€ / \mathrm{m}^{2}\right)$ relation to the balanced $\mathrm{CO}_{2}$ emissions $\left(\mathrm{kg}_{\mathrm{CO} 2} /\left(\mathrm{m}^{2} \mathrm{a}\right)\right)$ of all variants of the case study Solallén (related to treated floor area of the PHPP/energy tariff standard/user behaviour standard $/ \mathrm{CO}_{2}$ factors PHI/without consideration of subsidies/no $\mathrm{CO}_{2}$ credit for electricity fed into the grid).

Figure 8 the results look quite similar:

- The net present value ranges between $3.500 € / \mathrm{m}^{2}$ and $4.000 € / \mathrm{m}^{2}$. This is a range of about $15 \%$.

- The balanced $\mathrm{CO}_{2}$ emissions range between $14 \mathrm{~kg} /\left(\mathrm{m}^{2} \mathrm{a}\right)$ and $52 \mathrm{~kg} /\left(\mathrm{m}^{2} \mathrm{a}\right)$. This is a range of about $70 \%$.

The difference here is the fact that the lower the balanced $\mathrm{CO}_{2}$ emissions, the lower also the net present value gets. This shows that under the given boundary conditions $\mathrm{CO}_{2}$ emission reductions can be achieved while reducing the net present value of the building over the whole life-cycle at the same time.

The results look quite similar, achieving primary energy reductions of $66 \%$ between the variant with the lowest and the highest balanced primary energy demand (range of $83 \mathrm{kWh} /\left(\mathrm{m}^{2} \mathrm{a}\right)$ to $243 \mathrm{kWh} /\left(\mathrm{m}^{2} \mathrm{a}\right)$ ).

\subsection{Technology combinations and solution sets}

In a second step different combinations of technologies were investigated to test the influence on net present value, $\mathrm{CO}_{2}$ emissions and primary energy demand again. Following Figures 9 and 10 show exemplary evaluations of different technology options.

\subsection{Robustness}

The robustness of the technical solution sets and design strategies can be tested by assessing the design performance indicators for different user behaviours. The performance of a robust building will show less variation due to the difference in user types than a less robust 


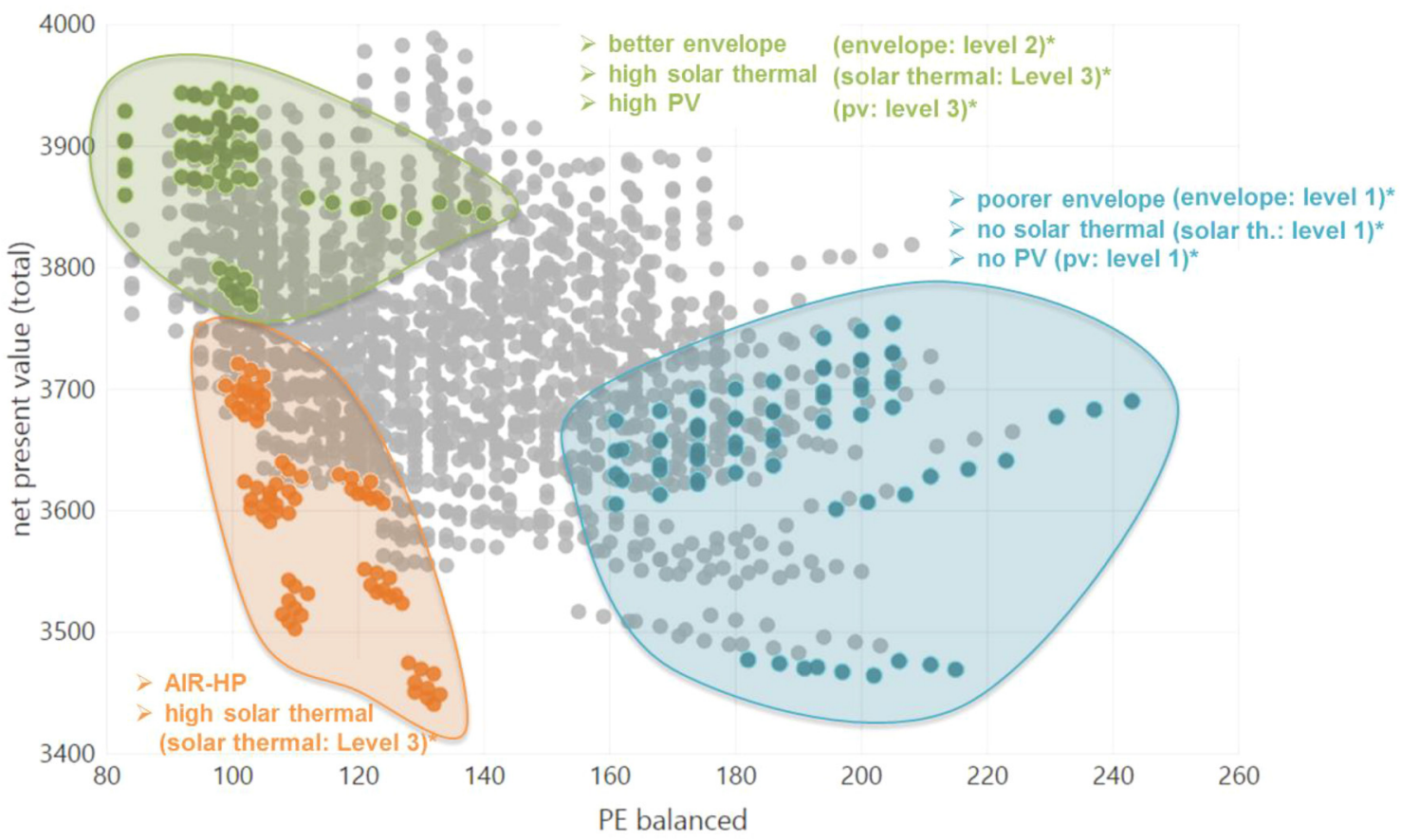

Fig. 9. Analysis of the balanced primary energy demand related to the net present value for the different technology combinations (related to the treated floor area of the PHPP/energy tariff standard/user behaviour standard/PE factors PHI/without consideration of subsidies/no PE credit for electricity fed into the grid). * Further information on the different levels of the technologies are given in Tables 2 and A5.

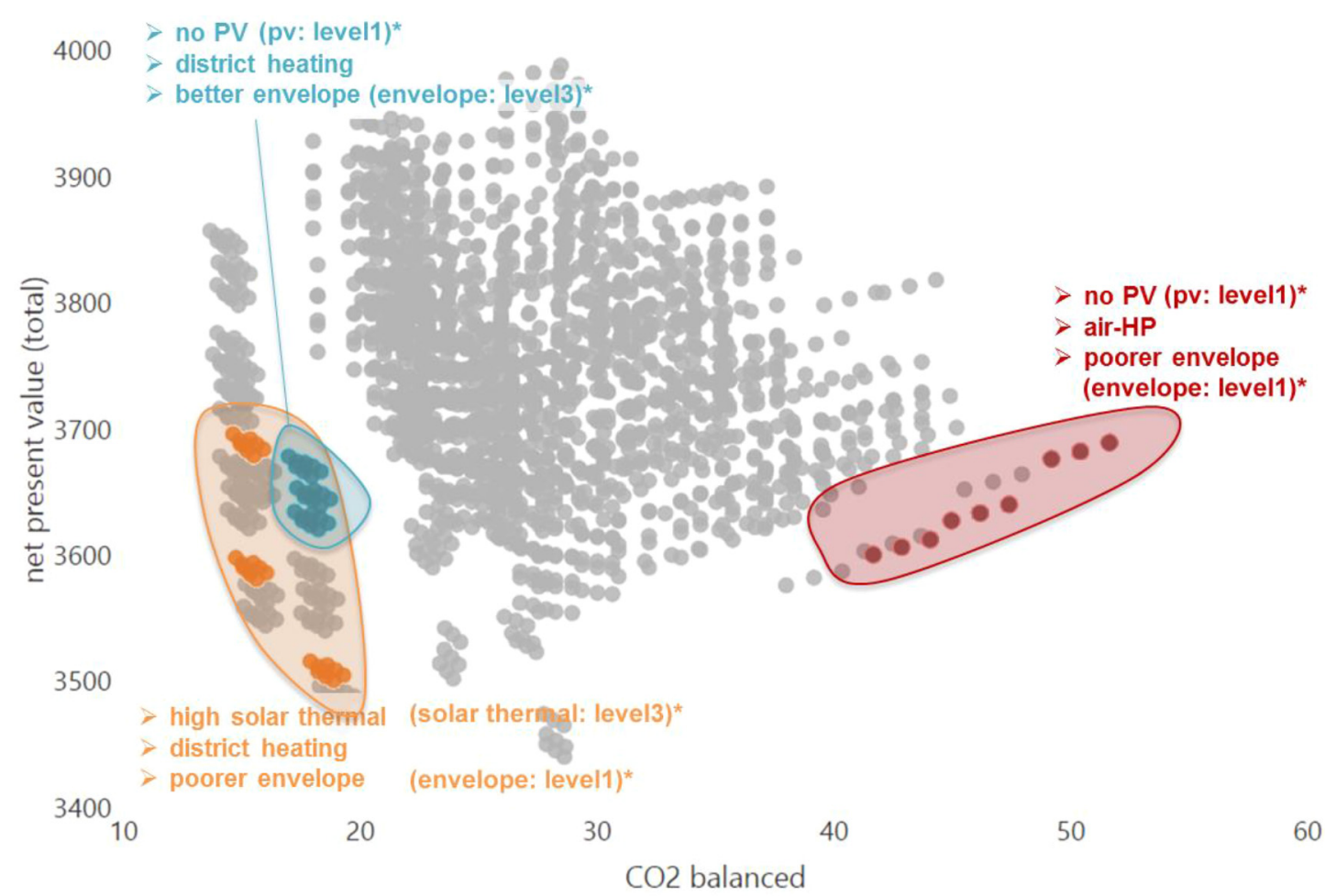

Fig. 10. Analysis of the balanced $\mathrm{CO}_{2}$ emissions related to the net present value for the different technology combinations (related to the treated floor area of the PHPP/energy tariff standard/user behaviour standard $/ \mathrm{CO}_{2}$ factors PHI/without consideration of subsidies $/$ no $\mathrm{CO}_{2}$ credit for electricity fed into the grid). * Further information on the different levels of the technologies are given in Tables 2 and A5. 
Table 3. Investigated user behaviour and assumptions.

\begin{tabular}{lllll}
\hline User behaviour & $\begin{array}{l}\text { Room temperature } \\
\text { in winter }\end{array}$ & DHW demand $\left(60^{\circ} \mathrm{C}\right)$ & $\begin{array}{l}\text { Additional shading in } \\
\text { winter due to misuse } \\
\text { of external blinds }\end{array}$ & $\begin{array}{l}\text { Additional window ventilation } \\
\text { in winter due to misuse }\end{array}$ \\
\hline Ideal & $21^{\circ} \mathrm{C}$ & $25 \mathrm{~L} /$ pers $/ \mathrm{d}$ & $+0 \%$ & $+0.001 / \mathrm{h}$ \\
Standard & $22^{\circ} \mathrm{C}$ & $30 \mathrm{~L} /$ pers $/ \mathrm{d}$ & $+10 \%$ & $+0.051 / \mathrm{h}$ \\
Inefficient & $23^{\circ} \mathrm{C}$ & $35 \mathrm{~L} /$ pers $/ \mathrm{d}$ & $+20 \%$ & $+0.101 / \mathrm{h}$ \\
\hline
\end{tabular}
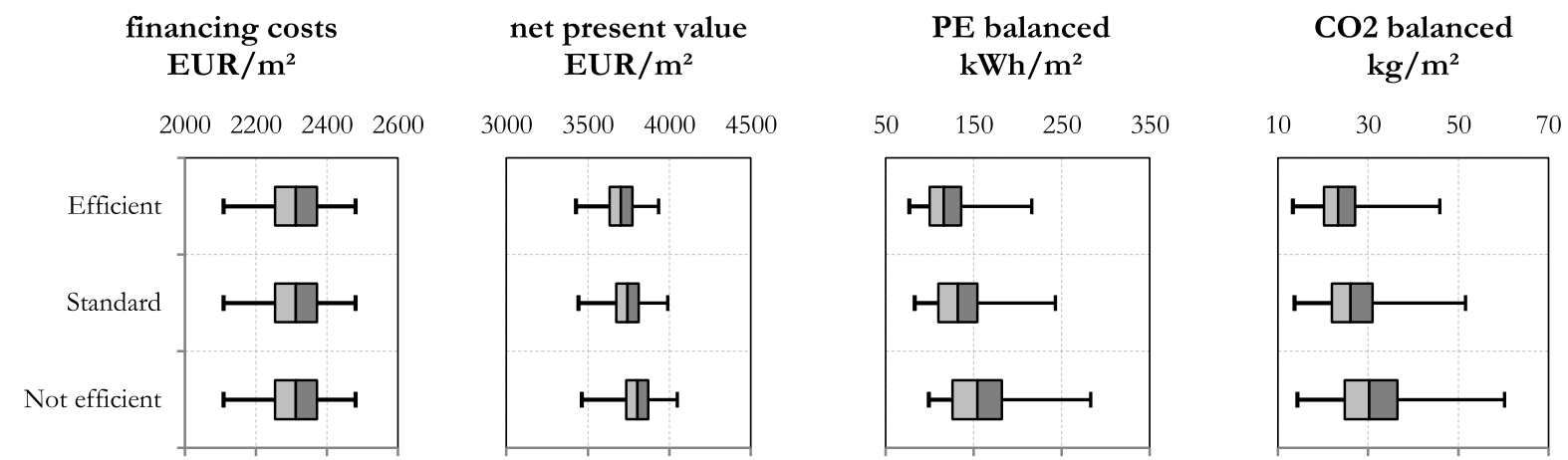

Fig. 11. Testing the robustness of the building by analysing the sensitivity of the financing costs, the net present value, the balanced primary energy (PE) demand and the balanced $\mathrm{CO}_{2}$ emissions to different user behaviour.

Table 4. Mean value and standard deviation of the investigated user behaviour.

\begin{tabular}{lllll}
\hline User behaviour & $\begin{array}{l}\text { Financing } \\
\text { costs }\left(€ / \mathrm{m}^{2}\right)\end{array}$ & $\begin{array}{l}\text { Net present } \\
\text { value }\left(€ / \mathrm{m}^{2}\right)\end{array}$ & $\begin{array}{l}\text { PE balanced } \\
\left(\mathrm{kwh} / \mathrm{m}^{2} \mathrm{a}\right)\end{array}$ & $\begin{array}{l}\mathrm{CO}_{2} \text { balanced } \\
\left(\mathrm{kg} / \mathrm{m}^{2} \mathrm{a}\right)\end{array}$ \\
\hline $\begin{array}{l}\text { Not efficient } \\
\quad \text { Median }\end{array}$ & 2.344 & 3.958 & 154 & 30 \\
$\quad$ Standard deviation & 187 & 260 & 35 & 9 \\
Standard & & & 132 & 26 \\
$\quad$ Median & 2.344 & 3.895 & 28 & 7 \\
$\quad$ Standard deviation & 187 & 259 & & 23 \\
Efficient & & & 116 & 6 \\
$\quad$ Median & 2.344 & 3.852 & 24 & \\
$\quad$ Standard deviation & 187 & 260 & & \\
\hline
\end{tabular}

building. Therefore, the deviation in the results can be used as a measure of robustness. In order to assess robustness, it is necessary to define the user behaviour, which is defined as follows in PHPP and as can be seen in Table 3 .

The results of the analysis are shown in Figure 11 and Table 4.

The user behaviour had a major influence on the total energy consumption of a building. A highly efficient building can at least support the user to reduce its energy consumption further.
Table 5. Weighting factors of optimization goals.

\begin{tabular}{lll}
\hline & $\begin{array}{l}\text { Weighting } \\
\text { factor }\end{array}$ & Share \\
\hline Balanced primary energy demand & 3 & $19 \%$ \\
Balanced $\mathrm{CO}_{2}$ emissions & 5 & $31 \%$ \\
Net present value & 5 & $31 \%$ \\
Financing costs & 3 & $19 \%$ \\
\hline
\end{tabular}




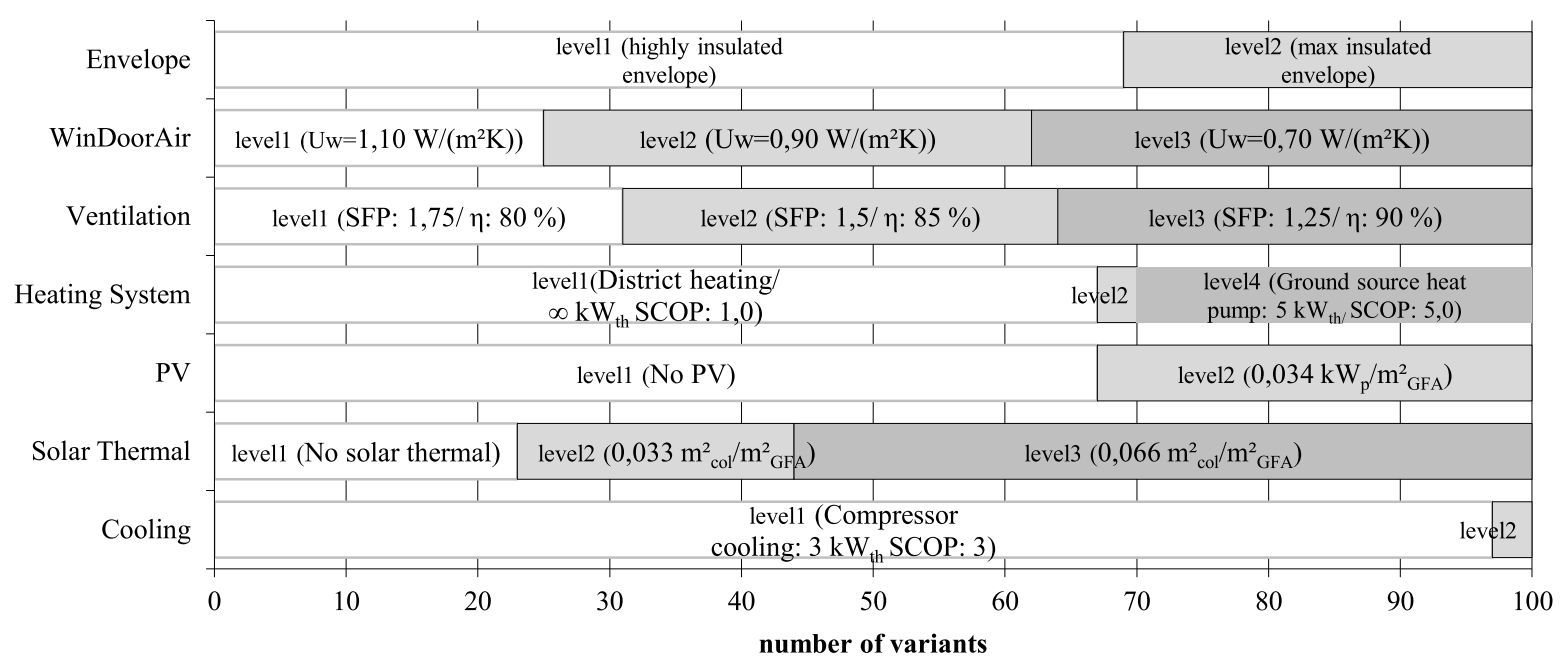

Fig. 12. Determination of the 100 variants per technology which achieve the best results according to the defined weighting of balanced primary energy demand, balanced $\mathrm{CO}_{2}$ emission, net present value and financing costs (energy tariff standard / user behaviour standard $/ \mathrm{CO}_{2}$ and $\mathrm{PE}$ factors $\mathrm{PHI} /$ without consideration of subsidies $/$ no $\mathrm{CO}_{2}$ or PE credit for electricity fed into the grid). More details on the different levels can be seen in Table 1 .

Table 6. Findings of parametric model analysis.

\begin{tabular}{llllllll}
\hline Technology & $\begin{array}{l}\text { Building } \\
\text { envelope }\end{array}$ & $\begin{array}{l}\text { Windows, doors } \\
\text { and air tightness }\end{array}$ & Ventilation & Heating & Cooling & Solar thermal & PV \\
\hline $\mathrm{CO}_{2}$ emissions & $+/-$ & + & - & + & + & $+/-$ & - \\
Primary energy & + & + & - & - & - & + & - \\
\hline
\end{tabular}

\subsection{Multi-target decision-making framework}

The choice of optimal variants is a multi-criteria decisionmaking process, which is affected by the objective/ optimization goal, and thus to each stakeholder perspective. Therefore, it depends on involved stakeholder perspectives as well as on the weight of each stakeholder in the decision process. As described in Section 2 the proposed methodology supports this process by allowing for multiple optimization goals that can be set into relation to each other and can be given a specific weighting.

The proposed optimization goals namely balanced primary energy demand, balanced $\mathrm{CO}_{2}$ emissions, financing costs and net present value different can be given different importance. For each optimization goal, the minimum value and the maximum value were accounted with a score from 0 (e.g. the highest $\mathrm{CO}_{2}$ demand) to 100 (e.g. the lowest $\mathrm{CO}_{2}$ demand). This rating was applied to all four optimization goals. Based on the weighting factors in Table 5 , each ranking score was weighted, which means the share of each indicator on the total score. Using the balanced $\mathrm{CO}_{2}$ emissions as an example, the weighted factor of 5 means a share of $31 \%$ of the overall summed ranking of the indicators. So those 100 variants could be determined which fulfil the set importance most (top 100).
The result of the calculation is shown in Figure 12. For each technology, those 100 variants are indicated which achieve the best results according to the defined weighting.

\section{Findings}

The energy, environmental and financial viability and the life cycle costs of 30.000 integrated building solutions are assessed for a multi-family residential building in the cold climate of Sweden. The analyzed solutions include different options for eight design variables: Air tightness, windows, ventilation system, heating system, photovoltaics, solar thermal system, cooling system, user behaviour and energy tariffs that are each classified into a maximum of three levels.

Determining the best global solutions for nZEB design variables, in terms of and cost performance, is a callenging task, mainly because the variables affect each other through processes that are often not linear, and the optimisation goal of each variable can change significantly based on the optimisation goal and the importance of the optimsation goals (financing costs, net present value, primary energy demand, $\mathrm{CO}_{2}$ emissions). In all variants, energy efficiency measures have only a small percentage 
influence on construction costs but can save many times more $\mathrm{CO}_{2}$ emissions. If regarded over the whole life cycle of the building, these efficiency measures are then usually cost-neutral or even economical. Among the main findings are the following:

- The range between the highest and lowest value is:

- Financing costs: $20 \%$ or $400 € / \mathrm{m}^{2}$

- Net present value: $15 \%$ or $500 € /\left(\mathrm{m}^{2} \mathrm{a}\right)$

- Balanced $\mathrm{CO}_{2}$ emissions: $73 \%$ or $38 \mathrm{~kg} /\left(\mathrm{m}^{2} \mathrm{a}\right)$

- Balanced primary energy demand: $66 \%$ or $160 \mathrm{kWh} /$ $\left(m^{2} a\right)$

- The influence of the parametric models on the balanced $\mathrm{CO}_{2}$ emissions and balanced primary energy demand can be summarised as follows (Tab. 6): ("+" . . influence existing, "+/_" . . p partial influence, "“" . . . no influence):

\section{Conclusions}

In nZEBs, low energy demand is achieved through insulation and passive strategies is essential in order to be able to provide the remaining energy demand for the building operation (heating, cooling, ventilation, domestic hot water, and lighting) with onsite renewable energy. nZEB measures only have a small percentage influence on construction costs, but can reduce $\mathrm{CO}_{2}$ emissions many times over. The cost reduction potentials for nZEB technologies until 2050 vary from approx. $1 \%$ to $65 \%$. Stationary batteries have the highest potential with $65 \%$, followed by decentralised ventilation, PV, centralised ventilation with $52 \%, 49 \%, 46 \%$ and $38 \%$ respectively. Oil and gas boilers have the lowest potential of less than $10 \%$. In many cases, the return of investment in energy efficiency measures to reach the nZEB target is around 25-40 years if calculated only in terms of energy cost saving. Nevertheless, as also assessed that the costeffectiveness of nZEB construction becomes more apparent if the co-benefits and revenues are included in the analysis. The cost optimum of primary energy demand and $\mathrm{CO}_{2}$ emissions is in the range of nearly zero and passive houses. Highly insulated envelopes and highly efficient windows are usually economical even without subsidies. This is also due to the long service life of these components in comparison to HVAC systems. The cost-optimum curve in relation to $\mathrm{CO}_{2}$ emissions is very flat. Low emissions and energy requirements can, therefore, be achieved with different energy concepts as long as the envelope is very efficient. This means architectural and conceptual freedom. The cost optimum of primary energy demand and $\mathrm{CO}_{2}$ emissions is in the range of nearly zero and passive houses. Highly insulated envelopes and highly efficient windows are usually economical even without subsidies. This is also due to the long service life of these components in comparison to HVAC systems.

In summary, the analyses offer a better understanding of the impacts that the technical nZEB design variables have on energy, environmental and economic performance of residential buildings in a heating dominated climate for multiple-objectives.
This work has been co-funded by the Horizon 2020 Framework Programme of the European Union within the project CRAVEzero - Grant Agreement No. 741223 (www.crave zero.eu).

\section{References}

1. EU, Directive 2010/31/EU of the European Parliament and of the Council of 19 May 2010 on the energy performance of buildings (recast), Off. J. Eur. Union 13-35 (2010)

2. M. Ferrara, V. Monetti, E. Fabrizio et al., Cost-optimal analysis for nearly zero energy buildings design and optimization: a critical review, Energies 11, 1-32 (2018)

3. E. Pikas, M. Thalfeldt, J. Kurnitski, Cost optimal and nearly zero energy building solutions for office buildings, Energy Build. (2014)

4. J. Kurnitski, A. Saari, T. Kalamees, M. Vuolle, J. Niemelä, T. Tark, Cost optimal and nearly zero (nZEB) energy performance calculations for residential buildings with REHVA definition for nZEB national implementation, Energy Build. 43, 3279-3288 (2011)

5. D. D'Agostino, D. Parker, A framework for the cost-optimal design of nearly zero energy buildings (NZEBs) in representative climates across Europe, Energy (2018)

6. BPIE, Nearly Zero Energy Buildings in Europe, 2016

7. S.P. Corgnati, E. Fabrizio, M. Filippi, V. Monetti, 'Reference buildings for cost optimal analysis: Method of definition and application, Appl. Energy (2013)

8. F. Garde et al., Design of net zero energy buildings: Feedback from international projects, Energy Proc. 61, 995-998 (2014)

9. BPIE, Cost Optimality: Discussing methodology and challenges within the recast Energy Performance of Buildings Directive, 2010

10. BSI ISO 15686-5, BS ISO 15686-5:2008-Buildings \& constructed assets - Service life planning - Part 5: Life cycle costing, Int. Stand. (2008)

11. A.T. Nguyen, S. Reiter, P. Rigo, A review on simulationbased optimization methods applied to building performance analysis, Appl. Energy (2014)

12. S. Attia, M. Hamdy, W. O'Brien, S. Carlucci, Assessing gaps and needs for integrating building performance optimization tools in net zero energy buildings design, Energy Build. 60, 110-124 (2013)

13. V. Machairas, A. Tsangrassoulis, K. Axarli, Algorithms for optimization of building design: a review, Renew. Sustain. Energy Rev. (2014)

14. US Department of Energy and others, A common definition for zero energy buildings, Change 5, 22 (2014)

15. E.M. Malatji, J. Zhang, X. Xia, A multiple objective optimisation model for building energy efficiency investment decision, Energy Build. (2013)

16. M. Hamdy, G.M. Mauro, Multi-objective optimization of building energy design to reconcile collective and private perspectives: CO2-eq vs. Discounted payback time, Energies (2017)

17. H. Iba, C.C. Aranha, Introduction to genetic algorithms, Adaptation, Learning, and Optimization (2012)

18. M. Fesanghary, S. Asadi, Z.W. Geem, Design of low-emission and energy-efficient residential buildings using a multiobjective optimization algorithm, Build. Environ. (2012) 
19. D. Tuhus-Dubrow, M. Krarti, Genetic-algorithm based approach to optimize building envelope design for residential buildings, Build. Environ. (2010)

20. J.A. Wright, H.A. Loosemore, R. Farmani, Optimization of building thermal design and control by multi-criterion genetic algorithm, Energy Build. (2002)

21. K.J. Lomas, H. Eppel, Sensitivity analysis techniques for building thermal simulation programs, Energy Build. (1992)

22. J.C. Lam, S.C.M. Hui, Sensitivity analysis of energy performance of office buildings, Build. Environ. (1996)

23. P. Heiselberg, H. Brohus, A. Hesselholt, H. Rasmussen, E. Seinre, S. Thomas, Application of sensitivity analysis in design of sustainable buildings, Renew. Energy (2009)
24. M.D. Morris, Factorial sampling plans for preliminary computational experiments, Technometrics (1991)

25. M. Cervantes, The Monte Carlo Method, Math. Sci. Eng. (1972)

26. University of Washington, Machine Learning: Clustering \& Retrieval. [Online]. Available: https://www.cour sera.org/lecture/ml-clustering-and-retrieval/complexityof-brute-force-search-5R6q3. [Accessed: 10-Apr- 2019]

27. G. Chiandussi, M. Codegone, S. Ferrero, F.E. Varesio, Comparison of multi-objective optimization methodologies for engineering applications, Comput. Math. Appl. (2012)

28. T. Hatt et al., Kostenoptimierte Gebäude im Lebenszyklus, in Economicum Session 7 (2018)

29. Passive House Institute, Passive House Planning Package (PHPP), passivehouse.com (2015)

Cite this article as: T. Weiss, C. Moser, D. Venus, B. Berggren and A. Togerro: Parametric multi-objective energy and cost analysis in the life cycle of nearly zero energy buildings - an exhaustive search approach. Sust. Build. 4, 5 (2019). 


\section{Appendix A: Boundary conditions}

See Tables A1-A5.

Table A1. Boundary condition for economic evaluation.

\begin{tabular}{ll}
\hline Economic boundary conditions & Reference \\
\hline Observation period of life-cycle cost & 40 years \\
Equity interest rate & $1.51 \%$ \\
Inflation rate & $2 \%$ \\
Discount rate & $3 \%$ \\
Credit period & 25 years \\
Interest rate bank credit & $3 \%$ \\
\hline
\end{tabular}

Table A2. Energy prices and net energy price increases as boundary conditions of the economic efficiency calculation.

\begin{tabular}{llll}
\hline $\begin{array}{l}\text { Energy } \\
\text { carriers }\end{array}$ & $\begin{array}{l}\text { Net prices } \\
\text { Sweden }\end{array}$ & Unit & $\begin{array}{l}\text { Price } \\
\text { increase [\%] }\end{array}$ \\
\hline Electricity & 0.187 & $€ / \mathrm{kWh}$ & 1.0 \\
District heating & 0.05 & $€ / \mathrm{kWh}$ & 1.0 \\
PV Feed-in grid & 0.03 & $€ / \mathrm{kWh}$ & 1.7 \\
\hline
\end{tabular}

Table A3. Summary of the most important maintenance costs and intervals.

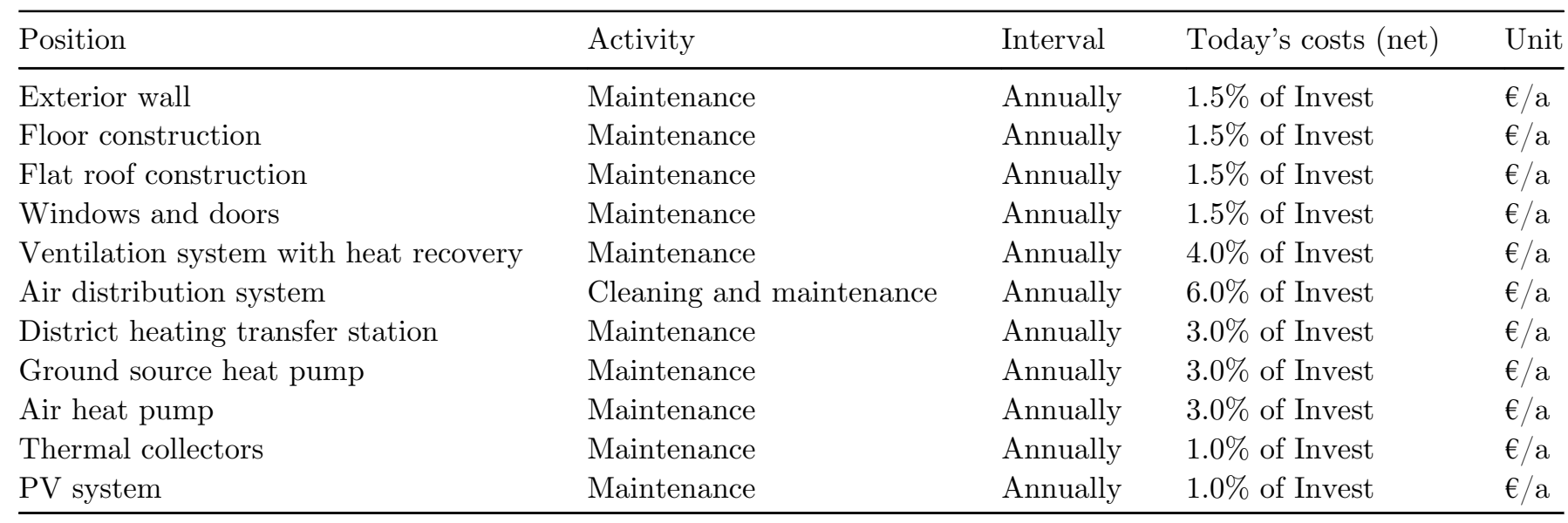

Table A4. Technical lifetime of prototypical nZEB elements.

\begin{tabular}{llll}
\hline Position & Techn. lifetime $(\mathrm{y})$ & Technology & Techn. lifetime (y) \\
\hline Exterior wall & 40 & Air heat pump & 20 \\
Floor construction & 40 & Buffer storage & 20 \\
Flat roof construction & 40 & Thermal collectors & 20 \\
Windows and doors & 40 & Ventilation unit with heat rec. & 15 \\
External sun protection & 40 & Air ducts, air distribution system & 30 \\
Interior wall and elements & 40 & Compressor cooling & 15 \\
Kitchen and bathroom furniture & 40 & Free cooling & 40 \\
Electric network & 25 & PV - modules & 25 \\
Heat distribution network & 30 & PV - inverter & 15 \\
Floor heating & 40 & Cables for PV and Inverter & 40 \\
District heating transfer station & 20 & Building automation system & 40
\end{tabular}


Table A5. Parameter cost data.

\begin{tabular}{|c|c|c|c|c|}
\hline & $\begin{array}{l}\text { Level 1: Poorer } \\
\text { performance }\end{array}$ & Level 2: As built & $\begin{array}{l}\text { Level 3: Better } \\
\text { performance }\end{array}$ & \\
\hline Parameter 1: Insulation & $\begin{array}{l}\text { Floor slab: } 200 \mathrm{~mm} \\
\text { insulation } \\
\text { Exterior walls: } \\
250 \mathrm{~mm} \text { insulation } \\
\text { Roof: } 450 \mathrm{~mm} \\
\text { insulation }\end{array}$ & $\begin{array}{l}\text { Floor slab: } 300 \mathrm{~mm} \\
\text { insulation } \\
\text { Exterior walls: } 455 \mathrm{~mm} \\
\text { insulation } \\
\text { Roof: } 600 \mathrm{~mm} \text { insulation }\end{array}$ & $\begin{array}{l}\text { Floor slab: } 400 \mathrm{~mm} \\
\text { insulation } \\
\text { Exterior walls: } 600 \mathrm{~mm} \\
\text { insulation } \\
\text { Roof: } 750 \mathrm{~mm} \text { insulation }\end{array}$ & \\
\hline Cost of floor insulation $€ / \mathrm{m}^{2}$ & 31.6 & 46.3 & 60.3 & \\
\hline Cost of exterior walls $€ / \mathrm{m}^{2}$ & 215.3 & 261.4 & 303.7 & \\
\hline Cost of roof insulation $€ / \mathrm{m}^{2}$ & 33.2 & 43.9 & 54.3 & \\
\hline $\begin{array}{l}\text { Labour in } \\
\text { (each construction?) } €\end{array}$ & $\begin{array}{l}\text { Floor slab: } 10.4 \text {; } \\
\text { Exterior walls: } 119.5 \text {; } \\
\text { Roof: } 12.7\end{array}$ & $\begin{array}{l}\text { Floor slab: } 14.5 \text {; } \\
\text { Exterior walls: } 151.2 \text {; } \\
\text { Roof: } 16.6\end{array}$ & $\begin{array}{l}\text { Floor slab: } 17.9 \text {; Exterior } \\
\text { walls: } 179.5 \text {; Roof: } 20.2\end{array}$ & \\
\hline Parameter 2: Air tightness & n50: 1.5 & n50: 0.84 & n50: 0.4 & \\
\hline Cost in $€$ & 6.00 & 10.40 & 12.80 & \\
\hline Labour in $€$ & 4.10 & 8.50 & 10.90 & \\
\hline Parameter 3: Windows/doors & $1.10 \mathrm{~W} / \mathrm{m}^{2} \mathrm{~K}$ & $0.90 \mathrm{~W} / \mathrm{m}^{2} \mathrm{~K}$ & $0.70 \mathrm{~W} / \mathrm{m}^{2} \mathrm{~K}$ & \\
\hline G-value of window & 0.37 & 0.37 & 0.37 & \\
\hline Cost in $€$ & 72397 & 75897 & 93397 & \\
\hline Labour in $€$ & 38512 & 38512 & 38512 & \\
\hline $\begin{array}{l}\text { Parameter 4: } \\
\text { Ventilation }\end{array}$ & $\begin{array}{l}\text { SFP: } 1.75 \\
\eta: 80 \% *\end{array}$ & $\begin{array}{l}\text { SFP: } 1.5 \\
\eta: 85 \%^{*}\end{array}$ & $\begin{array}{l}\text { SFP: } 1.25 \\
\eta: 90 \%^{*}\end{array}$ & \\
\hline$\overline{\text { Cost in } €}$ & 27043 & 31815 & 36587 & \\
\hline Labour in $€$ & 14175 & 14175 & 14175 & \\
\hline \multirow[t]{3}{*}{$\begin{array}{l}\text { Parameter 5: } \\
\text { Heating }\end{array}$} & District heating & $\begin{array}{l}\text { Ground } \\
\text { source } \\
\text { heat pump }\end{array}$ & $\begin{array}{l}\text { Ground } \\
\text { source } \\
\text { heat pump }\end{array}$ & $\begin{array}{l}\text { Extract } \\
\text { air heat } \\
\text { pump }\end{array}$ \\
\hline & $\mathrm{kW}: \infty$ & $\mathrm{kW}: 4$ & $\mathrm{~kW}: 5$ & $\mathrm{~kW}: 1.8$ \\
\hline & SCOP: 1.0 & SCOP: 3.5 & SCOP: 5.0 & $\begin{array}{l}\text { SCOP: } \\
2.5 \\
\end{array}$ \\
\hline $\begin{array}{l}\text { Total cost } \\
\text { in production }\end{array}$ & 121817 & 135352 & 155655 & 27070 \\
\hline Parameter 6: PVs & No PVs & $\begin{array}{l}66 \mathrm{~m}^{2} \\
10 \mathrm{kWp} \\
\end{array}$ & $\begin{array}{l}120 \mathrm{~m}^{2} \\
20 \mathrm{kWp}\end{array}$ & \\
\hline $\begin{array}{l}\text { Cost of PV modules }+ \\
\text { converters } €\end{array}$ & & 98000 & 190000 & \\
\hline Labour in $€$ & & 37450 & 70000 & \\
\hline \multirow[t]{2}{*}{ Parameter 7: STCs } & No STCs & $\begin{array}{l}10 \mathrm{~m}^{2} \mathrm{STC} \\
\text { standard } \\
\text { flate plate }\end{array}$ & $\begin{array}{l}20 \mathrm{~m}^{2} \\
\text { vacuum tubes }\end{array}$ & \\
\hline & & used for DHW & $\begin{array}{l}\text { used for DHW } \\
\text { and heating }\end{array}$ & \\
\hline Total material cost & & 16870 & 42840 & \\
\hline Labour in $€$ & & 7630 & 11760 & \\
\hline \multirow[t]{2}{*}{ Parameter 8: Cooling } & $\begin{array}{l}\text { Compressor } \\
\text { cooling } \\
\mathrm{kW}: 3\end{array}$ & $\begin{array}{l}\text { Free cooling/ } \\
\text { bore holes } \\
\text { kW: } 1\end{array}$ & $\begin{array}{l}\text { Free cooling/ } \\
\text { bore holes } \\
\text { kW: } 2\end{array}$ & \\
\hline & SCOP: 3 & SCOP: 20 & SCOP: 20 & \\
\hline Total cost & 10500 & 46995 & 70000 & \\
\hline
\end{tabular}

